\title{
KELTAMUUMIOTAUDIN TARTTUVAISUUDESTA SEKÄ SEN EHKÄISEMISESTÄ PARATION-VALMISTEILLA.
}

\author{
H. J. E. HÅRDH \\ Maatalouskoelaitoksen kasvitautiosasto, Tikkurila.
}

Saapunut 2. 3. 1951 .

Keltamuumiotauti ${ }^{1}$, jonka aiheuttaa Monilinia fructigena (ADERH. \& RUHL.) Honey (koteloaste Sclerotinia fructigena ADERH. \& RUHL.) (2) tavataan kaikilla maassamme yleisesti viljellyillä hedelmälajeilla. Seuraavassa tarkastellaan sienen patogeenisuuteen vaikuttavia tekijöitä omenalla sekä eräiden aineiden fungistaattista, s.o. sienen kasvua ehkäisevää tai hidastavaa vaikutusta taudin aiheuttajaan.

Monilinia fructigena- sieni turmelee hedelmiä mädättämällä ne ja muodostamalla niiden pinnalle hometta. Mädäntyneestä hedelmästä sieni kasvaa usein hedelmän kantaa pitkin kääpiöversoon ja tuhoaa sen osan versoa, joka on samana vuonna kehittynyt. Edellisen vuoden versoa ei sienen ole havaittu saastuttavan, mikä johtunee suojaavasta korkkikerroksesta tämän ja nuoren verson rajalla. Saastuneiden hedelmien ja versojen pinnalle kasvaa valkeita, myöhemmin kellertäviä homepisteitä, jotka hedelmissä ovat luonnollisissa olosuhteissa ryhmittyneet samankeskisiin renkaisiin saastutuskohdan ympärille. Näissä homepisteissä kehittyy suurin joukoin sienen kellertäviä, sitruunanmuotoisia kuromia, jotka leviävät tuulen, sadeveden, hyönteisten ja eräissä tapauksissa lintujenkin mukana ympäristöön (3). Jouduttuaan terveen hedelmän pinnalle suotuisiin olosuhteisiin kuromat itävät. Kuromista kasvavat sienirihmat eivät yleensä läpäise vahingoittumatonta omenan kuorta (13), tämä voi tapahtua vain milloin kosteusolosuhteet sienen kasvulle ovat erikoisen edulliset. Tällöin saattavat sienirihmat tunkeutua hedelmämaltoon kuoressa olevista korkkihuokosista (9). Sieni voi kasvaa sairaasta hedelmästä täysin vahingoittumattomaan hedelmään myös silloin, kun hedelmät koskettavat toisiaan puussa kasvuaikana. Näiden kosketuskohtaan kerääntyvä kosteus edistää tällöin sienen kasvua (15). Edellytyksenä sienirihmojen tunkeutumiselle hedelmän maltoon tavallisesti ovat kuitenkin hedelmien pintavioitukset. Tällaisia sopivia infektiokohtia omenan pinnassa ovat $\mathrm{mm}$. tuulen, rakeiden, tu-

1 Taudista on meillä käytetty myös nimitystä hedelmien muumiotauti. 
Taulukko 1. Eri tavoin inokuloitujen omenien muumiotautisaastunta.

Table 1. Infection of apples inoculated in different ways.

\begin{tabular}{|c|c|c|c|c|}
\hline $\begin{array}{l}\text { Inokulointi } \\
\text { Inoculation }\end{array}$ & $\begin{array}{l}\text { Lajike } \\
\text { Variety }\end{array}$ & $\begin{array}{l}\text { Inokuloituja } \\
\text { omenia kpl. } \\
\text { Apples } \\
\text { inoculated }\end{array}$ & $\begin{array}{l}\text { Saastuneita } \\
\text { omenia kpl. } \\
\text { Apples infec- } \\
\text { ted }\end{array}$ & $\%$ \\
\hline \multirow{4}{*}{$\begin{array}{l}\text { Sivelemällä kuromia terveen omenan pintaan } \\
\text { Conidia rubbed on healthy apples }\end{array}$} & Antonovka & 42 & 0 & \\
\hline & Bergius & 15 & 0 & \\
\hline & Charlottenthal & 64 & 0 & \\
\hline & & 121 & 0 & 0 \\
\hline \multirow{4}{*}{$\begin{array}{l}\text { Sivelemällä kuromia lievästi korkkiutuneen omenan } \\
\text { pintaan }{ }^{1} \\
\text { Conidia rubbed on surface with slight corking. }{ }^{1}\end{array}$} & Antonovka & 4 & 0 & \\
\hline & Bergius & 3 & 0 & \\
\hline & Charlottenthal & 2 & 0 & \\
\hline & & 9 & 0 & 0 \\
\hline \multirow{3}{*}{$\begin{array}{l}\text { Sivelemällä kuromia omenarupilaikkuihin } \\
\text { Conidia rubbed in apple scab spots }\end{array}$} & Antonovka & 3 & 2 & \\
\hline & Charlottenthal & 25 & 0 & \\
\hline & & 28 & 2 & 7.1 \\
\hline \multirow{2}{*}{$\begin{array}{l}\text { Sivelemällä kuromia ankarasti korkkiutuneen ome- } \\
\text { nan haljenneeseen pintaan } \\
\text { Conidia rubbed on surface of apples with severe cracking }\end{array}$} & Bergius & 10 & 2 & \\
\hline & & 10 & 2 & 20.0 \\
\hline \multirow{2}{*}{$\begin{array}{l}\text { Sivelemällä kuromia omenakääriäisen tekemään reikään } \\
\text { Conidia rubbed in hole made by codling moth }\end{array}$} & Antonovka & 4 & 3 & \\
\hline & & 4 & 3 & 75.0 \\
\hline \multirow{4}{*}{$\begin{array}{l}\text { Viemällä kuromia veitsellä hedelmän pintaan teh- } \\
\text { tyyn pieneen haavaan } \\
\text { Conidia placed in small wound made with knife-blade }\end{array}$} & Antonovka & 5 & 5 & \\
\hline & Charlottenthal & 2 & 2 & \\
\hline & Snygg & 5 & 5 & \\
\hline & & 12 & 12 & 100.0 \\
\hline
\end{tabular}

hohyönteisten, omenaruven [Venturia inaequalis (CoOkE) WINT.], ruiskutusnesteiden sekä epäedullisten kosteus- ja lämpösuhteiden aiheuttamat reiät, halkeamat ja korkkiutumat hedelmän pinnassa. Edellä sanotun perusteella on muumiotaudin torjunnassa tärkeä merkitys erilaisten pintavioitusten ehkäisemisellä. Tätä kysymystä selvittäviä tutkimuksia on aikaisemmin suoritettu mm. Englannissa (8), jossa Moore (12) sai muumiotaudin saastuttamien hedelmien määrän vähenemään $30 \%$ :lla, kun omenakääriäisen (Carpocapsa pomonella L.) ja omenaruven vioitukset ehkäistiin ruiskutuksin. Asia otettiin lähemmin tutkittavaksi myös Maatalouskoelaitoksen kasvitautiosastolla.

\section{Eri tavoin vioittuneiden omenien altius mumiotandille.}

Kokeet tehtiin v. 1948 ja 1949 Tikkurilassa kasvitautiosaston hedelmätarhassa lajikkeilla Antonovka, Bergius, Charlottenthal ja Snygg. Vuonna 1948, jolloin

1 Korkkiutuma $0.5 \%$ kuparikalkkiseoksen a'heuttamaa.

Corking due to copper-lime $0.5 \%$. 
koepuut olivat 4-vuotiaita, suoritettiin saastutuskoe siten, että kaikkiaan 65 hedelmää inokuloitiin viemällä $M$. fructigenan kuromia veitsen kärjellä hedelmien kuoreen tehtyihin haavoihin. Kaikki hedelmät saastuivat tällöin. V. 1949 inokuloitiin hedelmät $26 \mathrm{p}$. elokuuta siten, että $M$. fructigenan vastikään saastuttamien omenien pinnasta otettiin kuromia ja siveltiin niitä terveiden ja eri tavoin vioittuneiden hedelmien pintaan. Inokulointitavat sekä saastuntatulokset vuoden 1949 kokeesta esitetään taulukossa 1 .

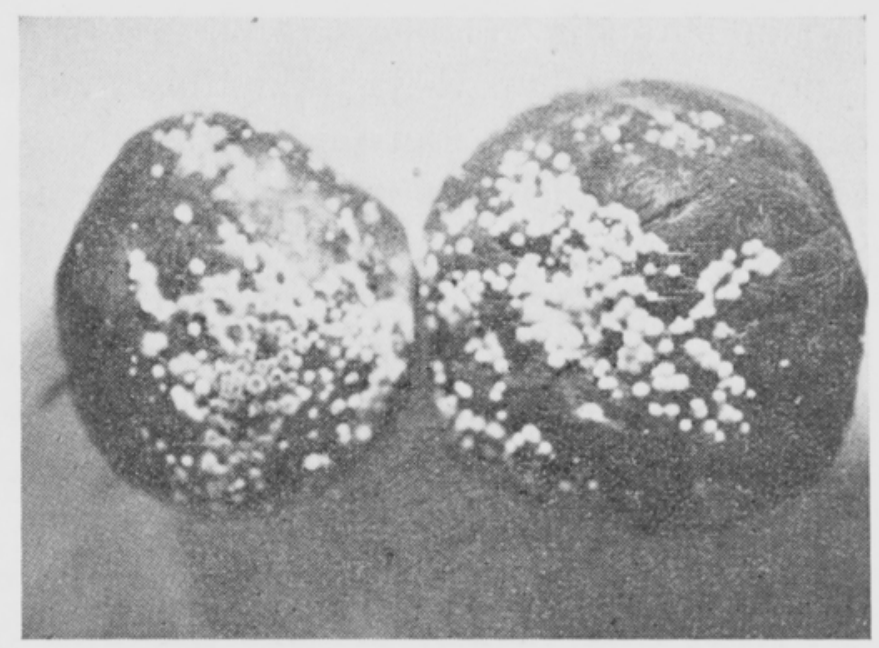

Kuva 1. Monilinia fructigenan turmelemia Astrakaani-omenia. Orig. - Fig. 1. Apples rotted by Monilinia fructigena. Variety Astrachan. Orig.

Taulukko osoittaa, että sieni ei näissä kokeissa pystynyt tunkeutumaan terveen hedelmän kuoren läpi. Lievästi korkkiutuneissa omenissa (vaalean ruskeata rosoutumaa hedelmän pinnassa) ei saastuntaa myöskään tapahtunut. Sen sijaan vahvasti korkkiutuneet hedelmät, joissa oli ruiskutusnesteiden aiheuttamaa pinnan epätasaisuutta tai halkeamia, saastuivat helposti muumiotautiin. Omenaruven aiheuttamissa laikuissa, joissa ei ole halkeamia, näyttää muumiotautisienen kasvu ja läpäisykyky olevan heikkoa. Sen sijaan halkeamat hedelmissä tarjoavat sienelle suotuisat kasvuolosuhteet. Näistä samoin kuin omenakääriäisen tekemistä reijistä voi sieni helposti tunkeutua omenamaltoon. Voimakkain saastunta saatiin inokuloimalla $M$. fructigenan kuromia veitsen kärjellä hedelmän kuoreen tehtyyn haavaan. Tällöin pilaantuivat kaikki inokuloidut hedelmät.

Selostetuista kokeista voidaan päätellä, että ehjä omenan kuori on esteenä $M$. fructigena- sienen tunkeutumiselle maltoon ja ehkäisee tehokkaasti muumiotautisaastuntaa. Kokeet osoittavat myös, että infektio tapahtuu sitä helpommin mitä suurempi on kasvualustan sekä ilman kosteus infektiokohdassa. Eniten on kosteutta hedelmän kuoreen syntyneessä reiässä tai halkeamassa, jonka pinta ei vielä ole korkkiutunut. Lähinnä edulliset olosuhteet muumiotautisaastunnalle näyttää olevan sellaisissa tapauksissa, jolloin maltoon ulottuva voimakkaiden ruiskutusnesteiden tai epäedullisten sääsuhteiden aiheuttama halkeama tai omenakääriäisen tekemä reikä on jo korkkiutunut. Tällaiset rikkoutumat ovatkin usein syynä hedelmien saastumiseen muumiotautiin. Terveet hedelmät sekä sellaiset, joissa on alkavia rupilaikkuja, saastuvat vain harvoin muumiotautiin. Tämä voi johtua paitsi hedelmän kuoren suojaavasta vaikutuksesta myös ilman vähäisestä kosteudesta lähinnä hedelmän pintaa.

\section{Eräiden aineiden fungistaattinen vaikutus $M . f r u$ c $t i g$ e $n$ a-sieneen}

Eri maissa tehdyt ruiskutuskokeet osoittavat, että omenarupea ja tuhohyönteisiä vastaan vuosittain suoritetut tavanomaiset ruiskutukset vähentävät kel- 
tamuumiotaudin vahinkoja $(4,5,7,12)$. Jos pintavioituksia hedelmiin kuitenkin syntyy, voivat kupari- ja rikkipitoiset ruiskutteet ehkäistä keltamuumiotautisaastuntaa vain silloin, kun jokainen syntynyt haava saadaan heti suojatuksi näillä aineilla (12). Ellei näin tapahdu, vaan sieni on jo saastuttanut hedelmän, ei infektion jälkeen suoritetuilla fungisidiruiskutuksilla voida ehkäistä hedelmän pilaantumista. Sen sijaan sellaisilla aineilla, jotka tunkeutuvat hedelmän kuoreen ja sen alla olevaan solukkoon, voi olla paremmat mahdollisuudet ehkäistä jo kuoren alle kasvaneen sienirihmaston kehitystä. FroHBERGER osoitti v. 1949, että tiofosfaattivalmisteet, joita käytetään tuhoeläinten torjuntaan, voivat tunkeutua hedelmän kuoreen ja maltoon (6). Samana vuonna BALDACcI (1) osoitti, että Parathionvalmiste (vaikuttava aine dietylnitrofenyltiofosfaattia) ehkäisee tällä aineella käsiteltyjen objektilasien pinnalle pantujen Sclerotinia fructigena- kuromien itämisen. Tiofosfaattivalmisteiden merkitys muumiotaudin torjunnassa ansaitsee näin ollen huomiota ja kysymys otettiinkin kasvitautiosastolla selvitettäväksi. Samalla tutkittiin eräiden muidenkin aineiden fungistaattista vaikutusta $M$. fructigenasieneen käsittelemällä omenia näillä aineilla ja inokuloimalla hedelmiin sen jälkeen sienen kuromia.

Kokeet suoritettiin v. 1949 laboratoriossa Charlottenthal-omenilla. Kokeiltavina olivat seuraavat aineet:

1. $0.1 \%$ sublimaattiliuos

2. $0.05 \%$ kuparisulfaattiliuos

3. $0.5 \%$ tanniiniliuos

4. $1 \%$ ferrosulfaattiliuos

5. $0.1 \%$ hydrokinoniliuos

6. $0.1 \%$ Cheminova-Parathion (sisältää $35 \%$ o-o dietyl-o-p nitrofenyltiofosfaattia, valmistaja A/S Cheminova, Tanska).

Nesteet laimennettiin vesijohtovedellä. Käsittely kullakin aineella tapahtui seuraavasti:

1. upottamalla omenat noin 2 sekunniksi nesteeseen

2. liottamalla omenia 24 tuntia nesteessä

3. liottamalla omenia 48 tuntia nesteessä.

Käsittelyn jälkeen annettiin hedelmien pinnan kuivua, tehtiin havainnot eri käsittelyjen vaikutuksesta hedelmiin sekä inokuloitiin hedelmät. Tällöin pistettiin steriloidulla veitsenkärjellä kuoreen tehtyyn reikään tuoreita $M$. fructigenakuromia. Kontrollin vuoksi inokuloitiin samalla tavoin myös käsittelemättömiä sekä vesijohtovedessä 24 tuntia liotettuja hedelmiä. Viimemainittu käsittely tapahtui laimennukseen käytetyn vesijohtoveden vaikutuksen toteamiseksi. Kullakin tavalla käsiteltiin 6 omenaa. Kun inokulointi oli suoritettu, pantiin hedelmät termostaattiin, jossa lämpötila oli kokeen aikana $+17^{\circ} \mathrm{C}$ ja ilman suhteellinen kosteus $95 \%$. Ensimmäinen analysointi suoritettiin 96 tunnin kuluttua inokuloinnista ja mittauksia sen jälkeen viisi kertaa 24 tunnin väliajoin. Kullakin kerralla mitattiin sienirihmaston aiheuttaman ruskean laikun halkaisijan pituus mm:ssä. Tulokset kokeesta esitetään taulukossa 2. 
Taulukko 2. Eri aineiden vaikutus omeniin sekä omenan mallossa etenevän $M$. fructigena-rihmaston kasvunopeuteen.

Table 2. Effect of certain liquids on the apples and on the growth rate of $M$. fructigena hypha in apple tissues.

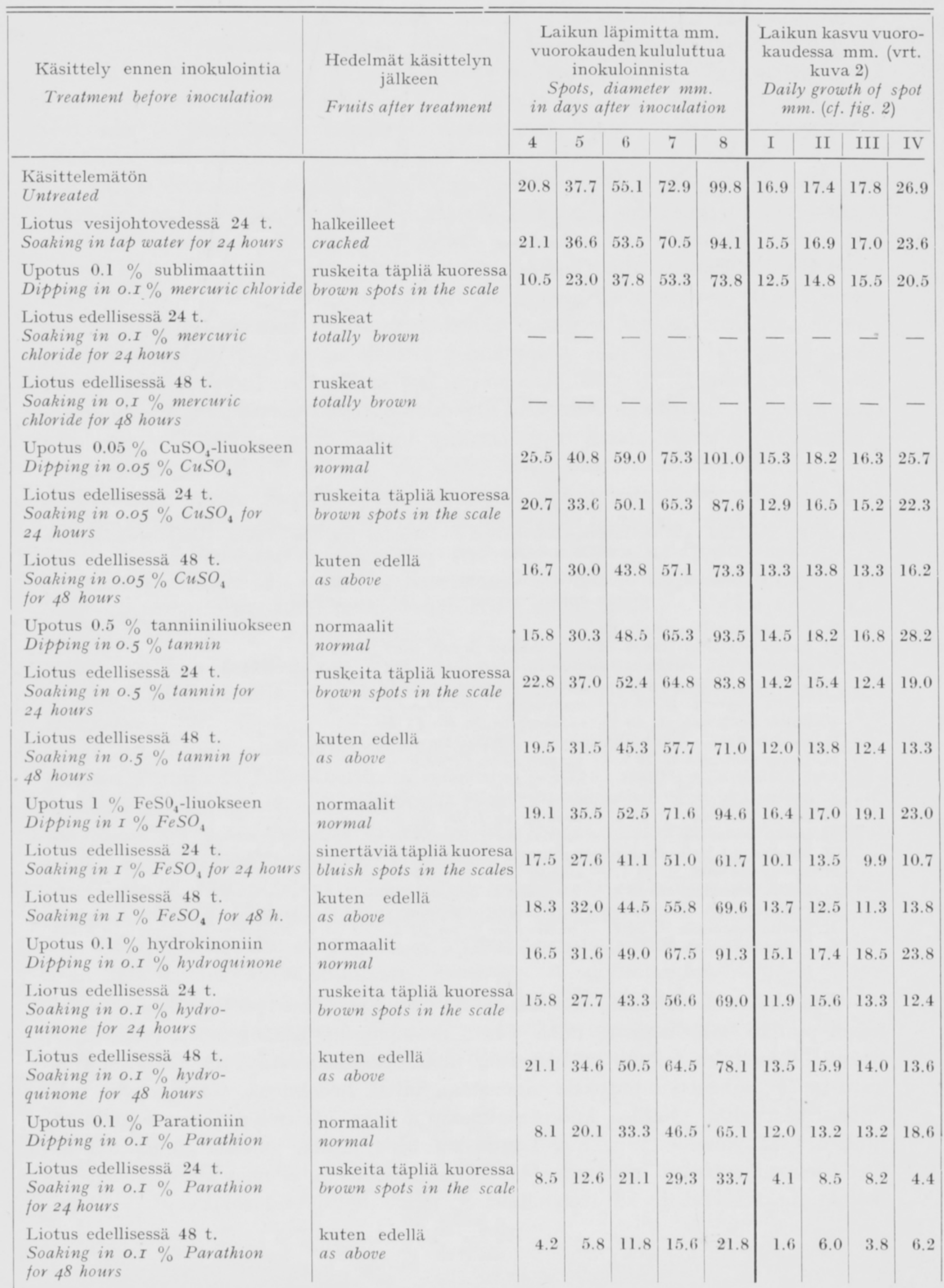




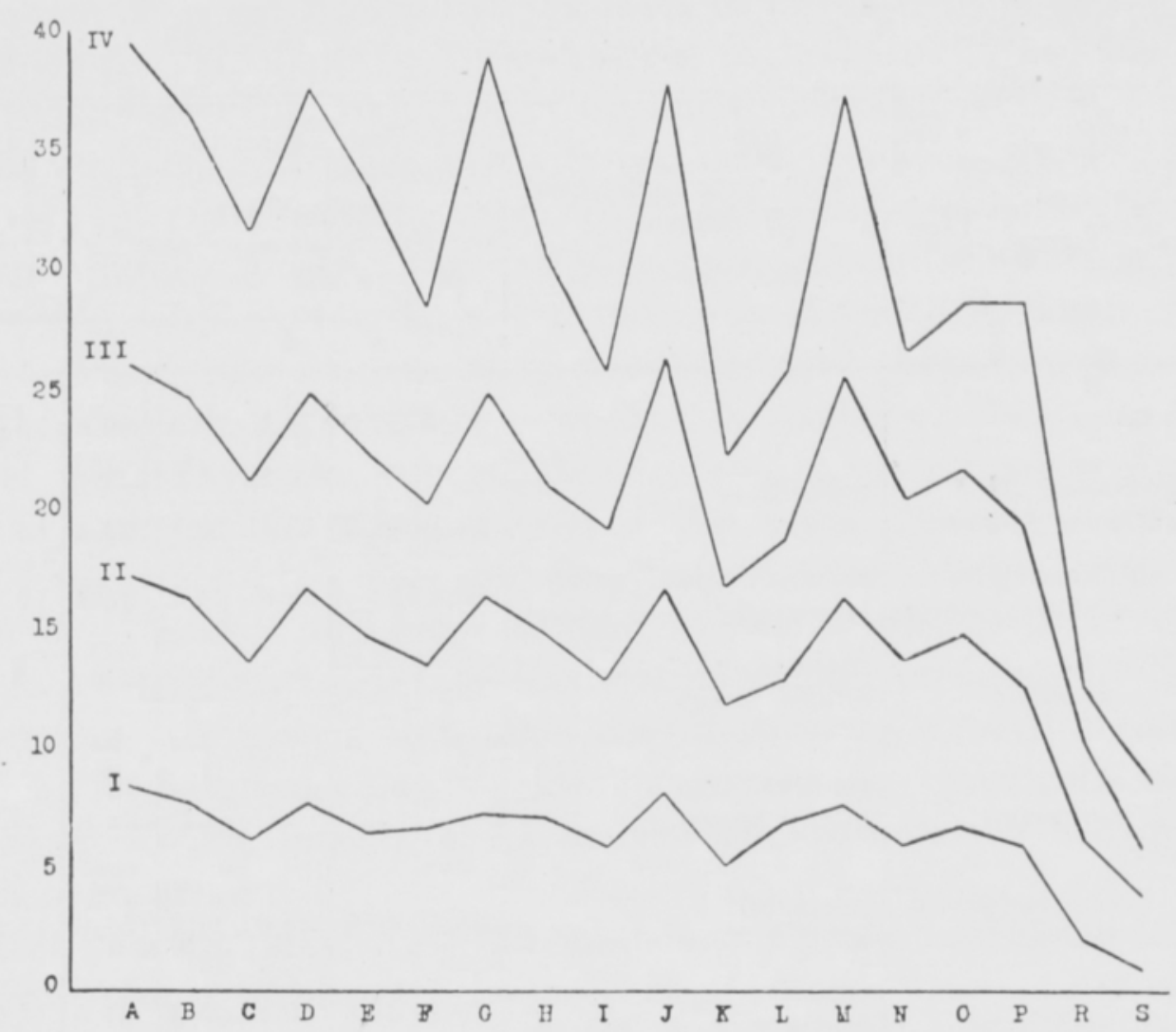

Kuva 2. Eri aineiden vaikutus omenan kuoren alla etenevän $M$. fructigenan rihmaston kasvunopeuteen I, II, III, IV $=1 ., 2 ., 3$. ja 4. vuorokauden aikana tapahtunut kasvu.

Fig. 2. Effect of certain liquids on the growth rate of $M$. fructigena hypha in apple tissues. $I, I I, I I I, I V=$ growth during the 1 st, 2 nd, $3 \mathrm{~d}$ and 4 th day.

A. käsittelemätön - untreated

B. liotus vesijohtovedessä $24 \mathrm{t}$. - soaking in tap water for $24 \mathrm{~h}$.

C. upotus $0.1 \%$ sublimaattiliuokseen - dipping in $0.1 \%$ mercuric chloride

D. upotus $0.05 \% \mathrm{CuSO}_{4}$-liuokseen - dipping in $0.05 \% \mathrm{CuSO}_{4}$.

E. liotus nesteessä D. 24 t. - soaking in D. for $24 h$,

F. liotus nesteessä D. 48 t. - soaking in D. for $48 h$.

G. upotus $0.5 \%$ tanniiniliuokseen - dipping in $0.5 \%$ tannin

H. liotus nesteessä G. 24 t. - soaking in G. for $24 h$.

I. liotus nesteessä G. 48 t. - soaking in G. for 48 h.

J. upotus $1 \% \mathrm{FeSO}_{4}$-liuokseen - dipping in $1 \% \mathrm{FeSO}_{4}$.

K. liotus nesteessä J. 24 t. - soaking in J. for $24 \mathrm{~h}$.

L. liotus nesteessä J. 48 t. - soaking in J. for $48 \mathrm{~h}$.

M. upotus $0.1 \%$ hydrokinoniliuokseen - dipping in $0.1 \%$ hydroquinone

N. liotus nestessä M. 24 t. - soaking in $M$. for $24 h$.

O. liotus nesteessä M. 48 t. - soaking in M. for $48 \mathrm{~h}$.

P. upotus $0.1 \%$ Cheminova-Parathioniin - dipping in $0.1 \%$ Cheminova-Parathion.

R. liotus nesteessä P. 24 t. - soaking in P. for $24 h$.

S. liotus nesteessä P. 48 t. - soaking in P. for 48 h.

Taulukosta 2. nähdään, että 24 tunnin liotus vesijohtovedessä aiheutti hedelmissä pinnan halkeilemista, mikä johtui nestepaineen lisääntymisestä hedelmän sisässä. Hedelmien upotus eri nesteisiin, mikä varkutukseltaan vastaa yhtä ruiskutusta (6), aiheutti muutoksia ainoastaan niissä hedelmissä, jotka saivat sublimaattikäsittelyn. Näiden kuoreen ilmaantui pian käsittelyn jälkeen pyöreitä, hiukan sisäänpainuneita, noin $2-3 \mathrm{~mm}$. suuruisia täpliä, jollaisia elohopeayhdisteet usein aiheuttavat hedelmiin (14). Sublimaatissa pitemmän ajan liotetut hedelmät ruskettuivat jo käsittelyn aikana, mikä johtui pintasolukkojen kuolemi- 
sesta. M. fructigenan kasvua ei solukon ruskettumisen vuoksi voitukaan seurata sublimaatissa liotetuissa hedelmissä. Liotus kuparisulfaatti-, tanniini-, ferrosulfaatti- ja hydrokinoniliuoksissa sekä Paration-emulsiossa aiheutti hedelmien kuoreen ruskeita laikkuja, jotka ulottuivat maltoon saakka. Useimmiten "nämä laikut syntyivät sellaisiin kohtiin, jotka olivat tavalla tai toisella mekaanisesti vioittuneet. Ferrosulfaattiliotuksen aiheuttamat laikut olivat sinisenharmaita, mikä ilmeisesti johtui omenissa olevasta tanniinista.

Tarkasteltaessa eri aineiden vaikutusta sieneen (kuva 2) havaitaan, että lyhytaikainen käsittely (upotus) kuparisulfaatti-, tanniini-, ferrosulfaatti- ja hydrokinoniliuksilla, joilla aineilla tiedetään olevan fungisidisia ominaisuuksia, ei vaikuttanut sienen kasvuun. Sen sijaan upotus $0.1 \%$ sublimaattiliuokseen sekä $0.1 \%$ Paration-emulsioon hidasti huomattavasti $M$. fructigenan kasvua. Liotettaessa hedelmiä 24 ja 48 tunnin ajan tunkeutui kokeiltavia aineita hedelmän maltosolukkoon ja ainekonsentratiot solukossa olivat todennäköisesti suuremmat kuin upotuskäsittelyn saaneissa hedelmissä. Tämä voidaan huomata siitä, että sienen kasvu hedelmässä oli sitä hitaampi, kuta pitemmän ajan hedelmää oli käsitelty nesteessä. Laimentamiseen käytetty vesijohtovesi vaikutti myös jonkin verran sienen kasvua hidastavasti. Tämä voi johtua joko veden sisältämistä rautasuoloista, tai muodostui anaerobisessa tilassa vedessä omenissa myrkkyaineita, joilla myös on voinut olla fungistaattisia ominaisuuksia. Liotuksen aikana hedelmän solukkoon tunkeutunut tiofosfaatti vaikutti voimakkaimmin sienen kasvuun. Injektiokokeissa on mm. Englannissa voitu imeyttää kasvaviin hedelmiin erilaisia aineita $(10,11)$. Tällaista menettelyä silmälläpitäen suoritettiin edellä mainitut kokeet liottamalla hedelmiä eri aineissa. Koska hedelmiin voidaan imeyttää aineita myös injektiomenetelmällä, joka jonkin verran on jo yleistynyt käytäntöönkin, saattavat edelläselostetut tulokset antaa viitteitä sisäistä terapiaa varten keltamuumiotautia ehkäistäessä.

Yllämainitulla, laboratoriossa käytetyllä menetelmällä voitiin tiofosfaattipitoisen Parationin fungistaattinen vaikutus osoittaa, mutta tiofosfaattien käytännöllisen merkityksen selvittämiseksi tässä suhteessa on kokeiltava luonnollisissa olosuhteissa ruiskutuksia vastaavien käsittelyjen vaikutusta samanaikaisesti hedelmiä vioittaviin hyönteisiin ja muumiotautisaastuntaan. Tämän vuoksi suoritettiinkin v. 1950 alustava ruiskutuskoe omenapuilla eräässä puutarhassa, jossa muumiotautia on esiintynyt runsaasti. Tällöin kokeiltiin $0.5 \%$ kuparikalkkiseoksen, 1:30 rikkikalkkiliuoksen ja $0.1 \%$ Cheminova-Parathionin vaikutusta hedelmien keltamuumiotautisaastuntaan. Ruiskutukset suoritettiin neljä kertaa. Parationilla käsiteltyjen koepuiden hedelmistä oli syksyllä $2.2 \%$ muumiotaudin saastuttamia, rikkikalkkiliuoksella ja kuparikalkkiseoksella käsiteltyjen sekä käsittelemättömien puiden hedelmistä oli tautisia vastaavasti $3.0,4.4$ ja $5.6 \%$. 


\section{Yhteenveto.}

1. Keltamuumiotaudin aiheuttaja, Monilinia fructigena (ADERH. \& RUHL.) HoNEY saastuttaa pääasiallisesti vioittuneita hedelmiä, joissa vioitukset johtuvat omenakääriäisen, epäedullisten säätekijöiden, omenaruven sekä voimakkaiden ruiskutusnesteiden vaikutuksesta. Tutkittaessa näiden vioitusten merkitystä hedelmien muumiotaudinalttiuteen todettiin, että saastunta tapahtuu harvoin lievään pintarosoon sekä sellaisiin omenarupilaikkuihin, joissa hedelmä ei ole halkeillut. Sen sijaan syvälle maltoon ulottuvat vioitukset, halkeamat ja reiät, joissa kasvualustan ja ilman kosteus lähimpänä hedelmän pintaa on suuri, ovat edullisia saastutuskohtia sienelle. Vahingoittumattomia hedelmiä ei sieni kokeissa lainkaan saastuttanut.

2. Eri aineiden fungistaattista vaikutusta kokeiltaessa todettiin, että omenan maltoon tunkeutunut Paration-aine hidastaa huomattavasti $M$. fructigena-sienen kasvua. Tämän aineen merkitys muumiotautia ehkäisevänä tekijänä voi perustua osittain tiofosfaattien tuhohyönteisiä torjuvaan ominaisuutteen osittain fungistaattiseen vaikutukseen, joka aineella todettiin olevan $M$. fructigena-sieneen.

\section{KIRJALLISUUS.}

(1.) Baldacci, E. 1949. Fungicidal action of phosphoric esters (Parathion). Abstracts of communications, IInd International Congress of Crop Protection, p. 49.

(2.) Buchwald, N. F. 1949. Studies in the Sclerotiniaceae I. Taxonomy of the Sclerotiniaceae. Den Kgl. Veterinaer- og Landbohøjskoles Aarsskrift 1949, p. 75-191.

(3.) Cunningham, G. H. 1925. Brown-rot, Sclerotinia cinerea Schroet. New Zealand Dept. of Agric., Bull., 101, p. 1-11.

(4) Esbjerg, N. 1929. Forsøg med Rentabiliteten ved Sprøjtning af Aebletraer I. Tidsskrift for Planteavl, 35 p. 517-565.

(5) Faes, H., Staehelin, M. \& Bovey, P. 1947. La défense des plantes cultivées, p. 1-654. Lausanne 1947.

(6) Frohberger, P. E. 1949. Untersuchungen über das Verhalten des Insektizids Diäthyl-p-nitrophenyl-thiophosphat (E 605) quf und in der Pflanze. Höfchen-Briefe für Wissenschaft und Praxis 2, 2, p. 10-90.

(7) Hammond, A. A. 1922. Spraying experiments for brown rot of stone fruit (Sclerotinia fructigena). Journ. Agric. Victoria, 20, p. 182-189.

(8) Harris, R. V. 1948. Plant Pathology. Ann. Rept. East Malling Res. Sta. 1947, p. 37-39.

(9) Horne, S. A. 1933. Biological work on fruit. Dept. Sci. \& Industry Res., Rept. Food Invest. Board for the year 1932, p. $279-300$.

(10) Levy, B. F. G. 1947. Preliminary Experiments on the Injection of Individual Apple Fruits on the Tree. Journ. Pomol., 23, p. 134-136.

(11) - - 1947. Tree Injection I, II \& III. Rept. East Malling Res. Sta. 1946, p. 99-112

(12) Moore, M. H. 1950. The brown-rot problem. Gardeners Chronicle, Ser. 3, 127, p. 99-100, 104.

(13) Noack, M. 1928. Ascomycetes. P. Sorauer, Handbuch der Pflanzenkrankheiten, II, 1, p. 448-737.

(14) Tiegs, E. 1934. Rauchschäden. P. Sorauer, Handbuch der Pflanzenkrankheiten, I, 2, p. 243-309.

(15) Weber, A. 1936. Aeblesygdomme under opbevaringen, p. 1-40. København 1936. 
S U M M A R Y.

ON THE PATHOGENICITY OF MONILINIA FRUCTIGENA (Aderh. \& Ruhl.) Honey AND CONTROL WITH PARATHION.

H. J. E. HÅRDH

Agricultural Research Centre, Department of Plant Pathology,

Tikkurila, Finland.

The significance of fruit lesions of different kinds in brown-rot infection has been investigated. M. fructigena conidia were rubbed with a paint brush on the surface of apples uninjured and injured in different ways. All the uninjured fruits remained healthy. Slight injury done by copperlime 0.5 $\%$ (Cuprosan 3 ) and smallish spots, without cracking of the fruit, due to apple scab (Venturia inaequalis) were also unfavorable to the penetration of the brown-rot fungus. Infection in the former case was $0 \%$, in the later $7.1 \%$ of apples inoculated. The inoculation of apples with severe corking and cracking resulted in $20.0 \%$ infection and the inoculation of fruits injured by the codling moth (Carpocapsa pomonella) in $75.0 \%$ respectively. All the fruits were infected when conidia were placed in a wound made with a knife-blade. It is thought that the susceptibility of lesions of different kinds to the brown-rot fungus is chiefly due to the moisture of the substrate and the air in the immediate proximity of the growing hypha.

Spraying with the usual fungicides appears to be successful in controlling the brown-rot disease only if every fresh wound is covered (12). The control of apple scab and codling moth is also of importance, to avoid lesions made by these. It was thought that a compound penetrating the fruit tissues might be effective in controlling the disease through inhibiting the growth of mycelium in the tissues. One such chemical penetrating the plant tissues is diethylnitrophenylthiophosphate (E 605) (6). Parathion is found to inhibit the growth of Sclerotinia fructigena conidia (1). The fungistatic action on the brown-rot fungus of Parathion and some other chemicals penetrating the fruit tissues was investigated in the laboratory by dipping apples of the variety Charlottenthal or soaking them for 24 and 48 hours in the liquids. Every treatment consisted of 6 apples. Table 2. shows the daily growth of the brown-rot spot on apples treated in different ways and inoculated. The growth rate is shown in figure 2. Dipping, which corresponds in effect to one spraying (6), in $0.1 \%$ mercuric chloride and in $0.1 \%$ Cheminova-Parathion retarded the growth of the fungus. Soaking for 24 hours in Parathion reduced the growth greatly, soaking for 48 hours made the growth poor. Soaking in $0.05 \%$ copper sulphate, $0.5 \%$ tannin, $1 \%$ ferrous sulphate and $0.1 \%$ hydroquinone, too, retarded the growth of the fungus.

The observations indicate that Parathion possesses an obvious fungistatic action on the brownrot fungus and is possibly efficient in controlling it. For this reason a preliminary spraying experiment was carried out in 1950. The results indicate that Parathion was the preparation most successful in controlling the disease. This is due to the fungistatic action of Parathion and also to its insecticidal properties. Further investigations are needed into the significance of Parathion compounds in the control of the brown-rot disease. 